\title{
Influence of Sr-Modification on Microstructure, Tensile, Impact and Hardness Properties of Secondary AISi8Cu2Mn Cast Alloy
}

Eva Tillová, Mária Chalupová, Lenka Kuchariková, Juraj Belan, Alan Vaško, Denisa Závodská

Faculty of Mechanical Engineering, University of Žilina, Univerzitná 8215/1, 01026 Žilina, Slovak Republic. E-mail: eva.tillova \{maria.chalupova; lenka.kucharikova; juraj.belan; alan.vasko; denisa.zavodska\}@fstroj.uniza.sk

Present work is focused on the study of recycled AISi8Cu2Mn cast alloy. Furthermore, the effect of Sr-modification $(0 ; 0.03$ and 0.05 wt. \%) on the microstructure, tensile and impact properties (UTS, ductility, hardness and impact energy) were investigated. For study and identification of intermetallic phases were utilized standard, colour and deep etching (in order to reveal the 3D-morphology of the Si-particles and intermetallic phases). For element composition of the specimen was used X-ray analysis. Finally, the effect of Sr-modification on silicon morphology was examined. The results show that the addition of $\mathrm{Sr}$ into AlSi8Cu2Mn cast alloy should act as a modifier, so it supposes to change the eutectic Si-morphology. However, its effect as a Si-modifier is not as significant. Higher number of iron (1.1\%) leads to an increase of precipitation of brittle iron phases with platelets $\left(\mathrm{Al}_{5} \mathrm{FeSi}\right)$ and skeleton-like $\left(\mathrm{Al}_{15}\left(\mathrm{FeMn}_{3} \mathrm{Si}_{2}\right)\right.$ morphology. $\mathrm{Al}_{5} \mathrm{FeSi}$ platelets act as preferred crack sites and reduce the tensile and impact properties. Strontium not only refined and modified eutectic Si, but also modified the $\mathrm{Al}_{5} \mathrm{FeSi}$ needles and thereby improves tensile (first of all ductility) and impact properties. Sr addition is also associated with porosity formation.

Keywords: Al-Si cast alloy, modification, tensile and impact properties, microstructure.

\section{Acknowledgement}

This study has been supported by the Scientific Grant Agency of the Ministry of Education of the Slovak Republic VEGA 01/0533/15 and KEGA 049ŽU-4/2017. The authors would like to thank Mrs. Anna Macúchová for preparation of metallographic samples.

\section{References}

[1] DAS, S. K., HUGHES, M. (2006). Improving Aluminum Can Recycling Rates: A Six Sigma Study in Kentucky. In: $J O M$, Vol. 8, No.8, pp. 27-31.

[2] DAS, S. K., GREEN, J. A. S. (2010). Aluminum industry and climate change - Assessment and responses. In: JOM, Vol. 62, No.2, pp. 27-31.

[3] SCHLESINGER, E. M. (2014). Aluminium Recycling, second ed., CRC Press.

[4] KUCHARIKOVÁ, L., TILLOVÁ, E., BOKU゚VKA, O. (2016). Recycling and properties of recycled aluminium alloys used in the transportation industry. In: Transport problems, Vol. 11, No. 2, pp. 117-122.

[5] https://www.european-aluminium.eu/resource-hub/aluminium-automotive-manual

[6] MAKHLOUF, M. M., GUTHY, H. V. (2001). The aluminium-silicon eutectic reaction: mechanisms and crystallography. In: Journal of Light Metals, Vol. 1, No.4, pp. 199-218.

[7] TILlOVÁ, E., CHALUPOVÁ, M. (2009). Structural analysis of Al-Si alloys, first ed., EDIS, Žilina.

[8] FABRIZI, A., FERRARO, S., TIMELLI, G. (2013). The influence of Sr, Mg and Cu addition on the microstructural properties of a secondary AlSi9Cu3(Fe) die casting alloy. In: Materials Characterization, Vol. 85, pp. 13-25.

[9] COMALCO (1997). Modification of foundry Al-Si alloys. Technical report No. 4., Comalco Aluminum Limited. Brisbane, Australia.

[10] KNUUTINEN, A., NOGITA, K., MCDONALD, S.D., DAHLE, A.K. (2001). Modification of Al-Si alloys with $\mathrm{Ba}, \mathrm{Ca}, \mathrm{Y}$ and Yb. In: Journal of Light Metals, Vol. 1, No. 4, pp. 229-240.

[11] STUNOVÁ, B. B. (2012). Strontium as a structure modifier for non-binary Al-Si alloy. In: Acta Polytechnica. Vol. 52, No. 4, pp. 26-32.

[12] FARKAŠOVÁ, M., TILlOVÁ, E., CHALUPOVÁ, M. (2013). Modification of Al-Si-Cu cast alloy. In: FME Transactions, New series, Vol. 41, No. 3, pp. 210-215.

[13] IBRAHIM, M. F., SAMUEL, E., SAMUEL, A. M., AL-AHMARI, A., SAMUEL, F. H. (2011). Impact toughness and fractography of Al-Si-Cu-Mg base alloys. In: Materials and Design, Vol. 32, No. 7, pp. 3900-3910. 
[14] ASM Handbook (2002). Vol.15 - Casting, ASM International.

[15] GROSSELLE, F., TIMELLI, G., BONOLLO, F. (2010). Doe applied to microstructural and mechanical properties of Al-Si-Cu-Mg casting alloys for automotive applications. In: Materials Science and Engineering: A, Vol. 527, No. 15, pp. 3536-3545.

[16] TillovÁ, E., CHAlupovÁ, M., HuRTAlovÁ, L., ĎURINÍKOVÁ, E. (2011). Quality control of microstructure in recycled Al-Si cast alloys. In: Manufacturing Technology, Vol. 11, No. 1, pp. 70-76.

[17] BOLIBRUCHOVÁ, D., ŽIHALOVÁ, M. (2013). Possibilities of iron elimination in aluminium alloys by vanadium. In: Manufacturing Technology, Vol. 13, No. 3, pp. 289-296.

[18] BOLIBRUCHOVÁ, D., RICHTÁRECH, L. (2013). Effect of adding iron to the AlSi7Mg0.3 (EN AC 42100 , A356) alloy. In: Manufacturing Technology, Vol. 13, No. 3, pp. 276-281.

[19] BORKO, K., TILlOVÁ, E., CHALUPOVÁ, M. (2016). The impact of Sr content on Fe - intermetallic phase's morphology changes in alloy AlSi10MgMn. In: Manufacturing Technology, Vol. 16, No. 1, pp. 20-26.

[20] CHO, Y.H., LEE, H. C., OH, K.H., DAHLE, A.K. (2008). Effect of Strontium and Phosphorus on Eutectic Al-Si nucleation and formation of $\mathrm{Al}_{5} \mathrm{FeSi}$ in hypoeutectic Al-Si foundry alloys. In: Metallurgical and Materials Transactions A, Vol. 39A, pp. 2435-2448.

[21] HARO-RODRÍGUEZ, S., GOYTIA-REYES, R. E., DWIVEDi, D. K., BALTAZAR-HERNÁNDEZ, V. H., FLORES-ZÚNIGA, H., PÉREZ-LÓPEZ, M. J. (2011). On influence of Ti and Sr on microstructure, mechanical properties and quality index of cast eutectic Al-Si-Mg alloy. In: Materials and Design, Vol. 32, Vol. 4, pp. 1865 1871.

[22] SUI, Y., WANG, Q., WANG, G., LIU, T. (2015). Effects of Sr content on the microstructure and mechanical properties of cast Al-12Si-4Cu-2Ni-0.8Mg alloys. In: Journal of Alloys and Compounds, Vol. 622, pp. 572-579.

[23] WANG, L., SHIVKUMAR, S. (1995). Strontium modification of aluminium alloy castings in the expendable pattern casting process. In: Journal of Materials Science, Vol. 30, No. 6, pp. 1584-1594.

[24] LIU, L., SAMUEL, A. M., SAMUEL, F. H., DOTY, H. W., VALTIERRA, S. (2003). Influence of oxides on porosity formation in Sr-treated Al-Si casting alloys. In: Journal of Materials Science, Vol. 38, No. 6, pp. 12551267. 